\title{
Kontribusi Penanganan Bencana Covid-19 oleh Muhammadiyah Disaster Management Center di Indonesia
}

\author{
Ardi Alfaris ${ }^{1 *}$, Riska Sarofah ${ }^{1}$, Irwandi ${ }^{1}$, Yusuf Fadli ${ }^{1}$, Nurhakim ${ }^{1}$ \\ 1 Universitas Muhammadiyah Tangerang, Indonesia \\ *Korespondensi: ardialfaris.biz@gmail.com
}

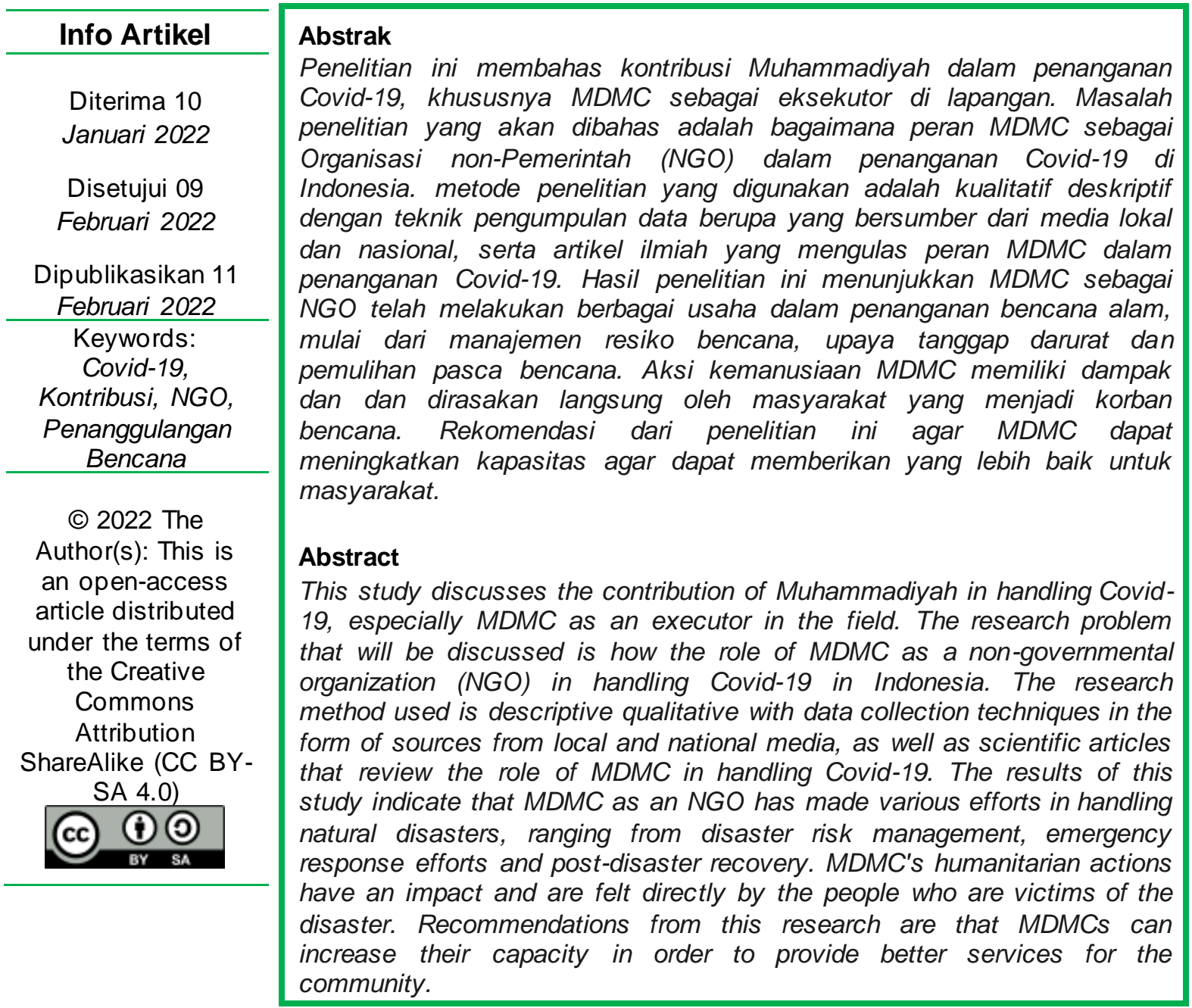

\section{Pendahuluan}

Penyebaran virus Covid-19 di Indonesia yang awalnya diprediksi dapat diatasi, ternyata menyebar dengan sangat cepat dan tidak terkendali (Tirto.id 2021). Tercatat penyebaran Virus Covid-19 mencapai puncak pada 15 juli 2021 , dengan total penambahan kasus positif baru sebanyak 56.757 (Covid19.go.id n.d.). hingga akhir Juli, penambahan Kasus covid-19 belum mengalami penu runan 
yang signifikan tercatat total 3.372.374 kasus positif, korban meninggal 92.311, dan pasien sembuh 2.730.720. (Merdeka.com 2021)

Negara melalui Satuan Tugas percepatan Penanganan Covid-19 telah berusaha sebaik mungkin dalam mencegah penyebaran virus. Mulai dari meningkatkan Testing, Tracing, and Treatment, memberlakuan kebijakan Pembatasan Sosisal Berskala Besar (PSBB), Pemberlakuan Pembatasan Kegiatan Masyarakat (PPKM) hingga melakukan vaksinasi massal (Liputan6.com 2021). Sayangnya hal tersebut belum mendapatkan hasil maksimal. Karena itu harus ada sinergi aktor negara dengan aktor non-negara dalam pencegahan penularan virus, hal ini dimaksudkan agar lebih banyak masyarakat yang dirangkul dalam upaya pencegahan penyebaran Covid-19.

Hal ini selaras dengan penuturan (Latief 2021) yang mengatakan bahwa negara tidak dapat sepenuhnya secara sempurna mengatasi bencana seorang diri.

"Transformasi lembaga filantropi Islam di Indonesia dan peran yang mereka mainkan untuk mengisi 'ruang kosong' dalam program pembangunan di berbagai bidang seperti pengentasan kemiskinan, penyediaan sarana pendidikan, layanan kesehatan, kelestarian lingkungan, ketahanan pangan, penanggulangan bencana alam dan sebagainya menjadi alasan mengapa UNDP dan BAPPENAS menggandeng lembaga filantropi Islam sebagai mitra mereka”.

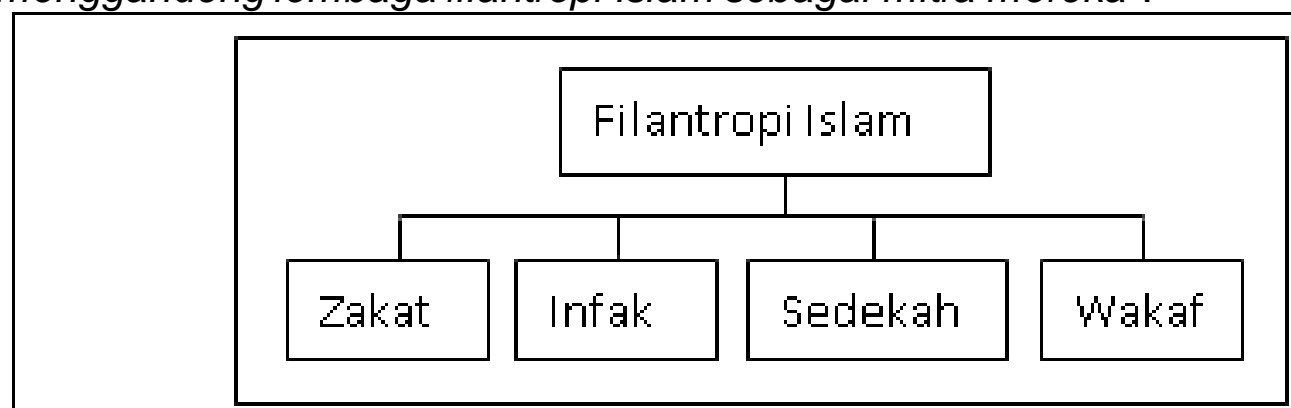

Gambar 1. Bentuk Filantropi Islam

Sumber: (Rizal dan Mukaromah, 2020)

Artinya, dalam hal penanganan bencana ada suatu kekosongan yang tidak dapat diisi oleh aktor negara, baik karena sangat luasnya wilayah terdampak bencana ataupun karena dampak bencana itu sendiri sangat besar. Aktor negara adalah lembaga pemerintah di berbagai tingkatan, sementara aktor non-negara meliputi organisasi non-pemerintah (Non-Government Organization/ NGO) yang bekerja di tingkat lokal dan secara langsung berinteraksi masyarakat (Koontz, Divya Gupta \& Tomas M., 2018).

Kolaborasi pemerintah dengan NGO menjadi hal penting dalam pencegah an dan penanganan Covid-19. Mengingat beberapa NGO merespon dengan cepat kasus merebaknya Covid-19. NGO merespon kejadian bencana secara efisien dengan membentuk jaringan komunikasi dan kerjasama diantara NGO, swasta, dan pemerintah setempat. Setiap NGO mengerahkan sumber daya yang mereka punya untuk berbagai bantuan seperti penggalangan dana, donor darah, distribu si logistik, mengirimkan relawan hingga menyiapkan tempat hunian sementara (Qing Liu, Raymond Yu Wang \& Heping Dang, 2018). Karena gerakan pengurangan risiko bencana oleh masyarakat sipil masih bersifat parsial. Maka, upaya 
konsolidasi pemerintah dan NGO secara simultan merupakan suatu kebutuhan strategis (Nugraha, 2018)

Muhammadiyah adalah NGO dengan sumbangsih terbesar. Sebagai organisasi masyarakat berbasis keagamaan terbesar Muhammadiyah telah menggelontorkan dana lebih dari 1 Triliun untuk membantu penangann Covid di Indonesia (CNN Indonesia 2021). Hal ini merunut kepada tujuan didirikannya Muhammadiyah itu sendiri berlandaskan teologi surah Al-Maun yang mencerminkan jiwa pemurah, dermawan, dan penolong. Pengejawantahan di lapangan Muhammadiyah menampilkan diri dalam bentuk gerakan amal (philantrophy movement) (Suaramuhammadiyah.id 2021). Hari ini teologi al-maun lebih dikenal masyarakat awam sebagai gerakan filantropi, istilah ini dapat dimaknai sebagai keikhlasan menolong, memberi sebagaian harta, tenaga ataupun pemikiran, dengan sukarela untuk kepentingan orang lain (Futaqi and Machali 2019). Dalam islam sendiri, filantropi diwujudkan dalam bentuk zakat, infak, sedekah dan wakaf (ZISWAF) yang bertujuan mengentaskan masalah sosial (Rizal and Mukaromah 2020), seperi kesenjangan ekonomi, pendidikan, dan tidak luput juga penaangan bencana alam. Praktek filantropi islam berupa ZISWAF sendiri dilakukan dengan sukarela diluar kewajiban kepada negara (Darojatu n and Alawiyah 2020).

Dalam menghadapi Covid-19 Muhammadiyah menekankan pada tiga strategi vital, yaitu kesiapan fasilitas kesehatan, eksekusi di lapangan, dan memberikan panduan keagamaan. Strategi eksekusi di lapangan yang membutuhkan perhatian dan keahlian khusus diserahkan kepada tim Muhammadiyah disaster Management Center (MDMC) yang mana menjadi satu-satunya Tim Darurat Medis (Emergency Medical Team/EMT) yang terdaftar di WHO (Suci, Napsuparman, and Rusman 2020).. Hal tersebut mendapat apresiasi yang baik dari presiden dan Menko Polhukam atas kerja keras Muhammadiyah dalam membantu penangan Covid-19 (Merdeka.com 2020).

Penelitian ini membahas sejauh mana kontribusi MDMC dalam penanggulangan bencan covid, dan apa saja bentuk kontribusi Muhammadiyah dalam penanganan Covid-19, khususnya MDMC sebagai eksekutor di lapangan. Sebelumnya telah ada penelitian yang melakukan riset mengenai peran MDMC dalam menghadapi Covid-19 diantaranya Mitigasi Bencana berbasis Dakwah Pencerahan. Penelitian tersebut menjabarkan bagaimana peran MDMC dalam pendampingan dan batuan psikologis untuk komunitas penyintas Covid-19. MDMC Sulawesi Tenggara meningkatkan kesadaran masyarakat akan bahaya Covid-19 dengan pendekatan kultural (lisan, brosur media sosial), pendekatan bi al-amal (penyemprotan, berbagi masker, berbagi makanan) dan dakwah pencerahan (kegiatan sosial untuk meingkatkan kesadaran) (Alifuddin, Chaer, and Sukatin 2021). Tetapi, penelitian ini hanya merekam kegiatan MDMC dalam pemulihan penyintas Covid yang mana ada di tahap akhir penganggulan bencana. Jadi tidak menyorot secara lengkap proses penanggulang an bencana Covid-19 oleh MDMC secara keseluruhan. Kemudian, penelitian selajutnya adalah Transformasi Kesalehan Sosial MDMC dalam Pembentukan Ruang Publik di tengah Pandemi Covid-19. Penelitian tersebut mengidentifikasi sekelompok orang yang kemudian dibuatkan sebuah gambaran umum kelompok tersebut dengan menggunakan kerangka epistemik untuk mempertimbangkan beberapa perspektif teoritis masalah Covid-19 di indonesia (Sadikin 2021). Dalam penelitian ini juga belum 
membahas peran MDMC dalam penanggulangan bencana Covid-19 secara utuh, penelitian hanya mengungkapkan cara-cara Muhammadiyah dalam mencegah bertambahnya paparan Covid-19 di masyarakat.

Penulis menemukan penelitian serupa yang pernah dibuat. Dalam pen elitian berjudul islamic philantrophy and Muhammadiyah's contribution to covid-19 control in indonesia telah disebutkan beberapa kinerja dari Muhammadiyah sebagai NGO. Penelitian tersebut menerangkan apa saja yang dilakukan Muhammadiyah dalam bidang agama, kesehatan, pendidikan, dan sosial (Khasanah and Purwaningsih 2021). Tetapi, penelitian tersebut dilakukan saat pandemi baru berjalan beberapa bulan. Sehingga data yang dicantumkan kurang up to date .

Dalam ketiga penelitian tersebut, masih memiliki kekurangan yaitu belum bisa mendeskripsikan apa saja yang sudah dilakukan MDMC dalam menangani Covid19 di Indonesia. Penelitian ini mencoba mengulas secara lengkap hal-hal yang sudah dilakukan oleh MDMC, mulai dari tahap perencanaan, miiigasi, kesiapsiagaan, peringatan dini, tanggap darurat bantuan darurat, pemulihan hingga tahap pumulihan, rehabilitasi dan rekonstruksi dalam penanggulangan bencana Covid-19. Yang mana artikel lain hanya membahas secara sebagian dari tahapan penanganan bencana. Selain itu metode penelitian sebelumnya hanya berfokus pada satu kegiatan MDMC di satu wilayah, dengan metode kajian pustaka dan analisis konten tertentu maka peneliti dapat melihat satu fenomena secara lebih luas dan jelas.

\section{Metode Penelitian}

Penelitian ini menggunakan metode kajian pustaka yang merupakan suatu penelitian terhadap bahan-bahan bacaan yang secara khusus berkaitan dengan objek penelitian yang sedang dikaji (Ratna, dalam (Ratini and Susanto 2018). Lebih lanjut kajian pustaka adalah suatu kegiatan yang bertujuan untuk mengumpulkan data dan juga informasi bersifat ilmiah, berupa teori, metode, atau pendekatan yang pernah berkembang atau telah di dokumentasikan dalam bentu $\mathrm{k}$ buku, jurnal, naskah, catatan, rekaman, dokumen-dokumen, dan lain-lain yang terdapat di perpustakaan (Pohan (dalam Yulianti, 2020)).

Penelitian akan menggunakan teknik pengumpulan data berdasarkan analisis konten, yaitu analisis yang digunakan untuk menentukan karakter dokumen atau membandingkannya dari media daring (Asfar, 2019), kemudian teks diinterpretasi secara deskriptif dan dihubungkan dengan fenomena yang ada. Dalam proses pengambilan data penulis mengcapture pemberitaan dalam media nasional dan lokal memiliki validitas serta keakuratan informasi yang baik, kemudian menyaring sumber bacaan yang relevan dengan topic penelitian. Artikel Jurnal yang digunakan adalah artikel yang sudah terindeks pada SINTA dan membahas tentang Muhammadiyah dan MDMC dalam penanganan bencana, khususnya Covid-19

\section{Hasil}

Dari berbagai sumber yang telah dirangkum, MDMC telah melakukan berbagai kegiatan dalam usaha membantu menanggulangi bencana Covid- 19 . Kegiatan penyaluran bantuan tersebut dimulai dari pra-bencana hingga pasca bencana. Secara garis besar MDMC telah melakukan kegiatan yang setidaknya 
mencakup 6 dari 8 aspek penanggulangan bencana, yaitu Kesiapsigaan, Mitigasi, Tanggap darurat, bantuan darurat, peringatan dini dan pemulihan.

Tabel 1. Kegiatan Penanggulangan Bencana oleh MDMC Indonesia

\begin{tabular}{|c|c|c|}
\hline No & Tahap Penanganan & Kegiatan yang dilakukan \\
\hline 1. & Kesiapsiagaan & $\begin{array}{ll}- & \text { Membentuk tim MCCC } \\
\text { - } & \text { Bekerjasama dengan pemerintah } \\
\text { setempat } \\
\text { - } \quad \text { Koordinasi kader } \\
\text { - } \quad \text { Kerja sama dengan WHO } \\
\end{array}$ \\
\hline 2. & Mitigasi & $\begin{array}{l}\text { - } \quad \text { Mengerahkan relawan } \\
\text { - } \quad \text { Pelatihan pembuatan tabung oksigen } \\
\text { darurat } \\
\text { - } \quad \text { Kerja sama dengan pemerintah } \\
\text { daerah } \\
\text { - } \quad \text { Mitigasi berdasar dakwah pencerahan }\end{array}$ \\
\hline 3. & Peringatan Dini & • ${ }_{\text {MCCC }}^{\text {Himbauan untuk masyarakat oleh }}$ \\
\hline 4. & Tanggap Darurat & $\begin{array}{ll}- & \text { Memakamkan jenazah Covid-19 } \\
\text { - } & \text { Mendirikan dapur umum } \\
\text { - } & \text { Penyemprotan disinfektan } \\
\text { - } & \text { Menyelenggarakan vaksinasi }\end{array}$ \\
\hline 5. & Bantuan Darurat & $\begin{array}{ll}\text { - } & \text { Memberikan peti jenazah } \\
\text { - } & \text { Membagikan hand sanitizer dan } \\
\text { masker } & \\
\text { - } \quad \text { Program ketahanan pangan }\end{array}$ \\
\hline 6. & Pemulihan & - $\quad$ Mendirikan pos koordinasi psikososial \\
\hline
\end{tabular}

Sumber: diolah dari berbagai sumber, 2021

\subsection{Kesiapsiagaan (Preparedness)}

Sejak awal penyebaran virus, MDMC bergerak cepat dengan membentuk tim khusus MCCC (Muhammadiyah Covid Command Center) untuk mengkoordinasikan berbagai program yang melibatkan seluruh jejaring Muhammadiyah termasuk penanggulangan Covid-19 di RS PKU Muhammadiyah (Tempo.co, 2020). Tim telah bekerja keras sejak dibentuk dan telah memperlihatkan banyak hasil di berbagai bidang, seperti bidang kesehatan, pendidikan, dan sosial (Khasanah \& Purwaningsih, 2021). Hingga 30 Juli 2021 tercatat terdapat 86 Rumah Sakit Pembina Kesejahteraan Umat (RS PKU) Muhammadiyah yang melayani pasien Covid-19 (MCCC, 2021a). Hal ini termasuk dalam upaya kesiapsiagaan Muhammadiyah dalam penanganan bencana yang dalam hal ini menjadi tugas dan tanggung jawab dari MDMC.

MDMC melalui MCCC Sleman bekerja sama dengan pemerintah setempat untuk menanggulangi Covid-19. Dalam prakteknya Pemerintah Kabupaten Sleman menjadikan MCCC sebagai mitra kerja pemerintah. Bagi pemerintah hal ini sebagai sarana untuk menjaring aspirasi dan bagi MDMC ini adalah kesempatan untuk mewujudkan aspirasi itu sendiri (Febty et al., 2020). 
MDMC juga mengkoordinasikan setiap kadernya untuk siap membantu meringankan beban warga akibat Covid-19. Seperti yang dilakukan oleh Koman do kesiapsiagaan Muhammadiyah (KOKAM) dan MDMC Blora, yang dipersiapkan sebagai garda terdepan dalam giat sosial di tengah pandemi Covid seperti edukasi dan pembagian masker/handsantizer, penyemprotan disinfektan dan kegiatan lainnya jika diperlukan (Jateng.tribunnews.com, 2021). Sosialisasi juga dilakukan dalam upaya memberikan penguatan kepada pelajar. Seperti yang dilakukan MDMC Kota Sorong dengan melakukan kampanye pencegahan Covid-19 pada siswa MTs Muhammadiyah 1 kota Sorong (Sorong.terkini.id, 2020a). Hal ini ditujukan agar siswa-siswa tidak berlebihan menghadapi Covid dan tetap menjaga pola hidup sehat.

Selain itu MDMC melalui MCCC juga bekerja sama dengan badan kesehatan dunia WHO. Kerja sama ini meliputi pelatihan manajemen klinis, pelatihan pengendalian infeksi, juga pembagian mobile $x$-ray beserta monitor (MCCC, 2021a).

\subsection{Mitigasi Bencana (Mitigation)}

Dalam mitigasi bencana, setidaknya terdapat beberapa usaha yang telah dilakukan. Muhammadiyah melalui MDMC telah berusaha semaksimal mungkin dalam mencegah tingkat penularan Covid-19 yang lebih ekstrem (Sadikin, 2021). Usaha tersebut seperti mengerahkan relawan untuk ikut menjaga protokol kesehatan dalam ajang Pekan Olahraga Nasional 2021 di Papua. Relawan MDMC tergabung dengan Relawan Prokes Merauka lain seperti Pramuka, LPBI NU, $P M K R I$ dan lain-lain. Dalam melakukan penguatan disiplin prokes dalam ajang PON XX Papua, para relawan membagikan masker serta memberikan edukasi kepada masyarakat Merauke. (Infopublik.id, 2021). Selanjutnya MDMC Jawa Tengah juga menggelar latihan pembuatan tabung oksigen daru rat seacara daring. Pelatihan didorong karena banyaknya korban meninggal disebabkan happy hypoxia atau kekurangan kadar oksigen dalam darah. Hal ini dimaksudkan untuk dan membantu pasien yang sedang kritis mengurangi korban meninggal akibat Covid-19 (Mettamedia.co.id, 2021).

Kemudian MDMC Sulawesi Tenggara melakukan mitigasi berdasar dakwah pencerahan. MDMC Sultra melakukan berbagai kegiatan sosial guna mendukung masyarakat dalam menghadapi Covid-19. MDMC Sultra juga melakukan meningkatkan kesadaran masyarakat akan bahaya Covid-19 dengan pendekatan kultural (lisan, brosur, media sosial), pendekatan bi al-amal (penyemprotan, berbagi masker, berbagi makanan) dan dakwah pencerahan (kegiatan sosial untuk meingkatkan kesadaran). Terakhir MDMC Sultra melakukan program penguatan masyarakat yang terdampak Covid-19 tanpa melihat agama, etnis, atau budaya melainkan berdasar pada urgensinya (Alifuddin et al., 2021).

MDMC juga turut ikut bekerja sama dengan pemerintah daerah. Seperti yang dilakukan pada Pembatasan Sosial Berskala Besar di DKI jakarta sejak maret 2020. Muhammadiyah yang diwakili MDMC dan MCCC memberi dukungan kebijakan penanganan Covid-19 yang sudah dilakukan Pemerintah Pusat, dan Pemerintah Provinsi DKI Jakarta, dengan melakukan kegiatan mitigasi atau pencegahan dan juga tindakan tanggap daru rat (Khasanah \& Purwaningsih, 2021). selain itu MDMC Yogyakarta juga bekerja sama dengan pemerintah DIY dalam penanganan Covid-19. MDMC Yogyakarta membentuk posko dukungan yang 
sejatinya memiliki 3 fungsi utama yaitu cipta kondisi, dekontaminasi dan pemulasaran jenazah Covid-19. Kerja sama ini menghasilkan pola hubungan yan g efektif antara MDMC sebagai NGO dan pemerintah daerah DIY (Khasanah \& Purwaningsih, 2021).

\subsection{Peringatan Dini (Early Warning)}

Semenjak Pemberlakuan Pembatasan Kegiatan Masyarakat (PPKM) mulai dilonggarkan, terdapat beberapa poin yang dilonggarkan seperti diperbolehkannya kompetisi olahraga, dibukanya restoran dan fasilitas olahraga, serta pekerja sektor non-formal dapat kembali bekerja di kantor. Angka infeksi yang menunjukkan penurunan memang hal yang baik. Tetapi, masyarakat tidak boleh terlena Wakil Ketua MCCC, dr. Aldila mengatakan bahwa hidup berdampingan dengan wabah bukan berarti kita bebas sepenuhnya dari kewajiban menjalankan prokes (MCCC, 2021b).

\subsection{Tanggap Darurat (Response)}

Dalam hal tanggap darurat, anggota MDMC Sragen ikut memakamkan jenazah pasien Covid-19 yang beragama katolik. Tim kamboja MDMC Sragen Tersebut telah memakamkan 14 jenazah Covid non-muslim dari 317 pemakaman. (Ibtimes.id, 2021). Hal tersebut menjadi solusi untuk masalah pemakaman dengan protokol Covid-19, dikarenakan tidak banyak yang mau melaksanakan tugas seperti ini dengan penuh kerelaan. Begitu juga yang dilakukan oleh MDMC Kudus, tim ikut melakukan pemakaman jenazah pasien Covid-19, tim MDMC Kudus ikut serta dalam memakamkan jenazah pasien Covid-19 setelah diminta ikut serta membantu seluruh rumah sakit (Inewsjateng.id, 2021). Selain itu, sebuah jurnal mengungkapkan bahwa program pemulasaraan jenazah Covid-19 yang dilakukan oleh Angkatan Muda Muhammadiyah yang tergabung dalam MDMC Palangkaraya, mendapatkan nilai yang baik (Kartini et al., 2021).

Di sisi lain, MDMC klaten juga mendirikan dapur umum untuk mencukupi logistik relawan dan warga yang menjalani isolasi mandiri di rumah (Timlo.net, 2021). Dapur darurat yang didirikan di salah satu rumah warga tersebut dapat mensuplai hingga 300 porsi makanan sehari. Dapur umum tersebut beranggotakan 10 orang Relawan Muhammadiyah. Kegiatan tersebut dilaksanakan sebagai bentuk kepedulian sosial dan berharap keadaan dapat kembali normal.

MDMC Sorong juga melakukan kegiatan peyemprotan disinfektan secara gratis. Penyemprotan tersebut menyasar 5 lokasi diantaranya: Lokalisasi Malanu ( Permintaan RT setempat dilakukan seminggu sekali); Komplek Kokoda Km 8 ada 3 RT; Komplek Jl. Madukoro RT 5 km.12; 4. SD Inpres 68 Klasaman Kota Sorong; dan SMP Nusantara km.13 Kota Sorong. Kegiatan penyemprotan tersebut berjalan hingga 3 pekan dimulai sejak 25 Maret 2020 (Sorong.terkini.id, 2020b). Secara nasional telah dilakukan penyemprotan disinfektan di 49.201 titik di seluruh Indonsia oleh tim gabungan dengan total pengeluaran dana sebesar Rp.865.862.285,- (MCCC, 2021a)

MDMC mendukung berbagai kegiatan vaksinasi di daerah-daerah. MCCC dibawah naungan MDMC bekerja sama dengan Amal Usaha Muhammadiyah lainnya seperti perguruan tinggi, rumah sakit dan klinik dengan total vaksinasi mencapai 168.123 jiwa. 
MDMC juga bekerja sama dengan Universitas Muhammadiyah Surakarta dalam program Gerakan UMS Peduli. Program ini berisi 3 macam kegiatan seperti penyemprotan disinfektan di fasilitas masyarakat, pembagian sembako dan juga sosialisasi protokol kesehatan (Ulinuha \& Fajariah, 2020).

\subsection{Bantuan Darurat (Relief)}

Merespon banyaknya kasus meninggal dunia akibat Covid-19 yang membutuhkan protokol khusus untuk pemakaman jenazah Covid-19, MDMC memberikan bantuan peti jenazah secara gratis. Hal ini terinsipirasi dari tim pemulasaraan jenazah muslim di Malaysia. Peti tersebut dibuat khusus bagi jenazah muslim agar dapat dimakamkan secara syar'i (Makassar.sindonews.com, 2021).

Bantuan lain berupa pemberian handsanitizerkepada Pemerintah Kabupaten Bangka Barat telah dilakukan oleh MDMC Bangka barat. Hal tersebut dalam rangka menekan penyebaran virus di tengah masyarakat (Portal.bangkabaratkab.go.id, 2021).

Selanjutnya melalui program ketahanan pangan, MDMC melalui MCCC berhasil merengkuh empat provinsi dan 115 kabupaten/kota di Jawa Tengah, Jawa Timur, DIY, dan Bali. Program ketahanan pangan tersebut berhasil mencapai 4388 jiwa, dengan rincian 4320 penerima program getapak dan 500 penerima dana Lazismu. Ditambah dengan bantuan dana untuk urban farming sebanyak 3520 jiwa, dan 800 penerima dana UMKM. MDMC menyalurkan bantuan berupa paket sembako kepada masyarakat di setiap daerah dengan total penerima 481.456 paket sembako (MCCC, 2021a).

\subsection{Pemulihan (Recovery)}

Pada tahap ini MDMC melakukan beberapa kegiatan untuk meningkatkan pemulihan keadaan setelah terdampak Covid. MDMC Jawa Tengah mendirikan Poskor dan menjadi relawan Psikososial. Dari laporan yang ditulis, Tim Psikososial MDMC memiliki dimensi-dimensi dalam altruisme, dimensi yang dimiliki secara kuat adalah empati, agama dan norma. Pada dimensi interpersonal dan hubungan timbal baik menjadi tidak dominan karena relawan tidak berharap un tuk mendapatkan balasan dari orang lain (Iftayani \& Setiawan, 2021). Hal ini menggambarkan keikhlasan setiap anggota MDMC dalam melayani masyarakat.

\section{Pembahasan}

Kontribusi sendiri diartikan sebagai uang iuran atau juga sumbangan (KBBI 2021). Kontribusi juga dapat didefinisikan sebagai peranan, masukan, ide atau perilaku yang dilakukan. Sedangkan peranan sendiri adalah bagian dari pelaksanaan tugas dan fungsi dalam suatu kegiatan atau kepentingan agar menghasilkan sesuatu yang berguna (Nurhazzanah 2016).

Bencana dapat dimaknai sebagai kejadian yang tidak diinginkan, seperti kecelakaan, banjir, kebakaran yang menyebabkan korban jiwa, atau dampak yang besar (Oxford 2021). Bencana alam dapat disebabkan oleh faktor geologi seperti gempa dan gunung meletus, faktor atmosfer seperti badai atau gelombang panas, dan faktor biologis seperti Pandemi (Rao 2020).

Untuk mengatasi hal tersebut, dibuatlah suatu prosedur disaster management (manajemen penanggulangan bencana). Ada tiga tahap yang 
termasuk kedalam manajemen penanggulangan bencana yaitu tahap pra-bencana dilaksanakan ketika sedang tidak terjadi bencana dan ketika sedang dalam ancaman potensi bencana, tanggap darurat bencana dirancang dan dilaksanakan pada saat sedang terjadi bencana, dan pasca bencana saat setelah terjadi bencana (BNPB provinsi bangka belitung 2021). Pandemi Covid-19 adalah bencana yang harus diselesaikan dengan bantuan dan dukungan berbagai pihak. Seperti organisasi ilmiah yang memberi informasi kepada tim pelaksana di lapangan untuk disosialisasikan kepada masyarakat (Rao 2020) seperti organisasi non-pemerintahan (NGO). NGO dapat memanfaatkan informasi atau hasil penelitian dari organisasi ilmiah untuk dapat berkontribusi dalam penanganan Covid-19.

Penanganan bencana Covid-19 sama seperti penanganan bencana pada umumnya. Adapun manajemen penanganan bencana Covid-19 terdiri dari:

a. Perencanaan dan pencegahan (Planning and Prevention). Yaitu upaya untuk mencegah terjadinya bencana sebisa mugkin dengan meniadakan bahaya.

b. Mitigasi (Mitigation) adalah upaya untuk mengurangi risiko atau dampak dari bencana.

c. Kesiapsiagaan (Preparedness) aktivitas yang ditujukan untuk antisipasi bencana dengan cara pengorganisasian dan langkah yang tepat dan berdaya guna. Hal tersebut meliputi penilaian risiko, perencanaan siaga, mobilisasi sumber daya, pendidikan dan pelatihan, koordinasi, mekanisme respons, manajemen informasi, dan gladi/simulasi.

d. Peringatan dini (Early Warning) adalah kegiatan pemberian peringatan untuk masyarakat tentang kemungkinan terjadi bencana.

e. Tanggap darurat (Response) upaya yang segera dilakukan ketika terjadi bencana, untuk menanggulangi dampak yang ditimbulkan, terutama berupa penyelamatan korban dan harta benda, evakuasi, dan pengungsian.

f. Bantuan darurat (Relief) adalah usaha memberikan bantuan untuk pemenuhan kebutuhan dasar

g. Pemulihan (Recovery) yaitu proses pemulihan kondisi masyarakat yang terdampak bencana dengan mengembalikan kembali prasarana dan sarana pada keadaan semula

h. Rehabilitasi dan rekonstrusi (Rehabilitation and Reconstruction) Rehabilitasi adalah langkah yang dilakukan setelah kejadian bencana guna membantu masyarakat memperbaiki fasilitas-fasilitas penting, dan menghidupkan kembali roda perekonomian. Sementara rekonstruksi adalah program jangka menengah dan panjang untuk perbaikan fisik, sosial, dan ekonomi, yang bertujuan untuk mengembalikan kehidupan masyarakat pada kondisi semula atau lebih baik. (Feriandi 2020) 


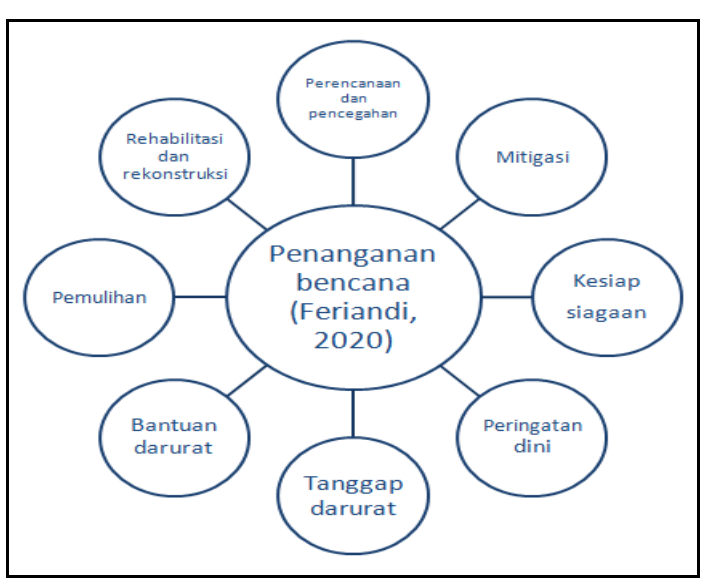

Gambar 2. Tahapan Penanggulangan Bencana

Sumber: (Feriandi, 2020)

Langkah-langkah yang dilakukan merupakan kegiatan sukarela dan panggilan kemanusiaan yang coba dipenuhi oleh Muhammadiyah khususnya MDMC. Muhammadiyah melihat bencana sebagai sesuatu yang rasional antara realita dan kaitannya dengan teks keagamaan, yang artinya, persoalan ini juga harus direspon secara rasional. Karena dalam pandangan islam kesadaran kemanusiaan melintasi ras, etnik, bahasa, agama, budaya, dan status lainnya (Muhammadiyah, 2015) Dalam pandangan fikih kebencanaan dalil dalam su rat al hujurat ayat 13 yang mengatakan ta'aruf bukan hanya berari saling mengenal tetapi juga saling menolong (Syariah et al., 2020).

Penanganan bencana dasarnya adalah wewenang pemerintah, tetapi masyarakat juga memiliki andil dan tanggung jawab dalam penanganan bencana. Sehingga Muhammadiyah sebagai anggota dari masyarakat itu sendiri juga memiliki tanggung jawab dalam hal penanganan bencana.

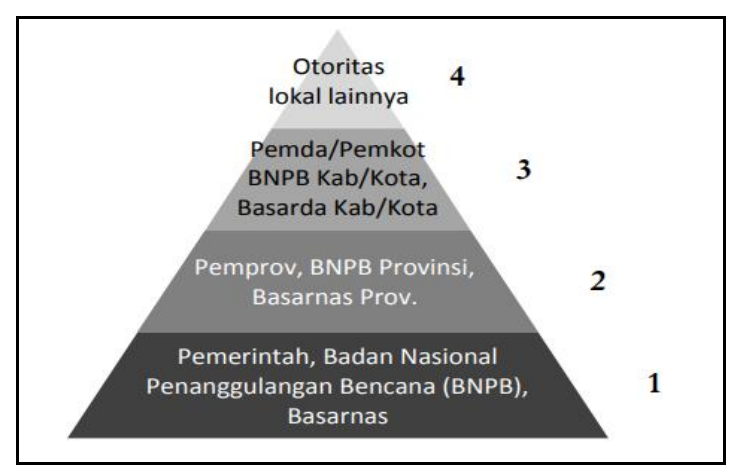

Gambar 3. Piramida otoritas penanggulangan bencana

Sumber: (PP Muhammadiyah, 2015)

Berangkat dari hal-hal demikian, Muhammadiyah memiliki kesadaran kolektif yang bersumber dari hati nurani tentang kebencanaan termasuk dalam hal bencana Covid-19, semangat gotong-royong dan kemanusiaan tersebut kemudian berkembang menjadi suatu solidaritas sosial.

Menurut Durkheim dalam (Hawkins \& Polytechnic, 1979) solidaritas sosial adalah kesadaran kolektif, cara berpikir dan perasaan bersama yang mengikat 
anggota masyarakat untuk bersama-sama membangun komunitas. Lebih lanjut, solidaritas sosial juga dibuat berdasarkan kesamaan dalam masyarakat.

Pandemi Covid-19 selain membuka kesadaran dan solidaritas atas nama kemanusiaan, membuat Muhammadiyah khususnya MDMC untuk membantu penanganan bencana Covid-19 yang menghantam berbagai lini kehidupan masyarakat. Maka sebagai respon rasional menghadapi keadaan, Muhammadiyah membentuk serangkaian kegiatan yang dinilai dapat membantu dan mengurangi dampak yang dirasakan masyarakat dari pandemi Covid-19. Kegiatan-kegiatan penanganan bencana Covid-19 tumbuh secara mekanik dan terprogram sejalan dengan struktur organisasi Muhammadiyah itu sendiri.

Di sisi lain pemerintah yang kurang maksimal dan tidak dapat menjangkau seluruh lapisan masyarakat ikut mendorong gerakan-gerakan sosio-humanis dalam meringankan dampak dari pandemi Covid-19 seperti hal yang dilakukan oleh Muhammadiyah dan MDMC

Menurut Singh, Kurangnya penanganan pemerintah dalam pandemi juga mendorong membuka ruang bagi pembentukan solidaritas, organisasi, dan kelembagaan adat, Ketika warga kehilangan kepercayaan pada kemampuan mereka untuk bekerja melalui saluran resmi, biara melampaui tradisional dan kontemporer batas untuk bekerja sama satu sama lain (Singh et al., 2021) sehingga gerakan sosial oleh komunitas semacam ini sangat eksis dimasa sekarang.

\section{Kesimpulan}

MDMC sebagai lembaga penanggulangan telah ikut dalam penanggulangan bencana Covid-19 dan telah berusaha melakukan yang terbaik dalam melakukan tugasnya sebagai lembaga penanggulangan bencana muhammdiyah. Dari 8 tahapan penanggulangan bencana, MDMC telah ikut serta dala 6 tahap yaitu;1) kesiapsiagaan (preparedness), 2) mitigasi (mitigation), 3) peringatan dini (early warning), 4) tanggap darurat (response), 5) bantuan darurat (relief), dan 6) pemulihan (recovery). Kegiatan penanggulangan bencana tersebut dilakukan diseluruh daerah di Indonesia dengan penerima manfaat hingga 712.709 jiwa. Dana yang dikeluarkan oleh MCCC sebagai tim khusus penanggulangan Covid-19 MDMC mencapai Rp. 117.333.265,471,-- Tetapi, hal tersebut belum mampu menjangkau seluruh masyarakat indonesia. Dikarenakan keterbatasan MDMC baik dari sisi personel ataupun akomodasi.

Melalui penelitian ini penulis hendak memberikan saran kepada MDMC khususnya MCCC sebagai tim khusus penanggulangan Covid-19 untuk dapat melakukan peningkatan kinerja dan kapasitas kader maupun lembaga agar bisa menjangkau masyarakat indonesia lebih luas lagi. Kemudian diharapkan MDMC dapat memasifkan publikasi kegiatan, dikarenakan masih sedikitnya publikasi kegiatan MDMC di setiap daerah..

\section{Ucapan Terima Kasih}

Penulis engucapkan puji syukur kepada Allah karena telah memberikan ijinnya untuk menyelesaikan penelitian ini. Juga kepada orang tua yang selalu mendukung dan memfasilitasi. Tidak lupa kepada setiap Dosen di fakultas IImu Sosial dan IImu Politik Universitas Muhammadiyah Tangerang untuk ilmu -ilmu yang berarti selama empat setengah tahun. 


\section{Daftar Pustaka}

Alifuddin, Muhammad, Moh. Toriqul Chaer, \& Sukatin Sukatin. (2021). "MitigationBased Enlightenment Da'wah (Social Movement of MDMC SulawesiSoutheast in Psychological Assistance to COVID-19 Survivors)." International Journal of Islamic Educational Psychology 2(1):86-106. doi: 10.18196/ijiep.v2i1.11759.

BNPB provinsi bangka belitung. (2021). "Proses Penanggulangan Bencana." Retrieved September 25, 2021 (https://bpbd.babelprov.go.id/prosespenanggulangan-bencana/).

CNN Indonesia. (2021). "Muhammadiyah Gelontorkan Bantuan Rp1 Triliun Selama Pandemi." 03 Agustus. Retrieved August 28, 2021 (https://www.cnnindonesia.com/nasional/20210803130339-20-

675741/muhammadiyah-gelontorkan-bantuan-rp1-triliun-selama-pandemi).

Covid19.go.id. n.d. "Peta Sebaran Covid-19." Retrieved August 28, 2021 (https://covid19.go.id/peta-sebaran-covid19).

Darojatun, Rina, \& Azizah Alawiyah. (2020). Konstruksi Kesalehan Sosial Generasi Muslim. Serang: Media Madani.

Febty, Inggi Miya, Sakir, D. Mutiarin, \& DE Rahmawati. (2020). "Government And Private Collaboration In Handling Covid-19 Pandemic In Sleman District." universitas mu hammadiyah yogyakarta.

Feriandi, Yudi. (2020). KOPIDPEDIA, Bunga Rampai Artikel Penyakit Virus Koronoa (Covid-19). 1st ed. edited by T. Respati and H. S. Rathomi. Bandung: P2U UNISBA.

Futaqi, Sauqi, \& Imam Machali. (2019). "Pembiayaan Pendidikan Berbasis Filantropi Islam: Strategi Rumah Pintar BAZNAS Piyungan Yogyakarta." MANAGERIA: Jurnal Manajemen Pendidikan Islam 3(2):231-56. doi: 10.14421/manageria.2018.32-02.

Ibtimes.id. (2021). "Lagi, MCCC Makamkan Jenazah Covid-19 Non-Muslim." 1 Juli, 1.

Iftayani, Itsna, \& . Budi Setiawan. (2021). Altruisme Relawan Psikososial Poskor PDB Jawa Tengah.

Inewsjateng.id. (2021). "Viral, Relawan MDMC Kudus Makamkan Jenazah Psien Covid-19 Non-Muslim." 25 Juni, 1.

Infopublik.id. (2021). "Relawan Prokes Merauke: Ini Adalah Tugas Panggilan Kemanusiaan." 3 Oktober 1. Retrieved October 7, 2021 (https://infopublik.id/kategori/pon-papua/569495/relawan-prokes-merauke-iniadalah-tugas-panggilan-kemanusiaan).

Jateng.tribunnews.com. (2021). "Kokam Dan MDMC Di Blora Siap Bantu Ringankan Beban Warga Di Tengah Pandemi." 14 Januari.

Kartini, Nurul Hikmah, Muhammadiyah Palangka Raya, \& Palangka Raya. (2021). "Evaluasi Program Relawan Angkatan Muda Muhammadiyah Pada Pemulasaran Jenazah Covid-19 Di Kalimantan Tengah Evaluation Of Muhammadiyah Young Generation Volunteer Program On Covid-19 Body 
Review In Central Kalimantan Abstrak." Anterior.

KBBI. (2021). "Kontribusi." Retrieved October 1, 2021 (https://kbbi.kemdikbud.go.id/entri/kontribusi).

Khasanah, R. P., \& T. Purwaningsih. (2021). "Analisis Collaborative Governance Dalam Implementasi Kebijakan Psbb Pada Penanganan Pandemi Covid-19 Di DKI Jakarta Tahun 2020.” Jurnal Pemerintahan Dan ... 2(3):155-69.

Latief, Hilman. (2021). “Transformasi Lembaga Filantropi Islam Mengisi Ruang Kosong Pembangunan." 30 Januari.

Liputan6.com. (2021). "5 Upaya Pemerintah Mengatasi-Pandemi Covid-19 Selain Ppkm Level-4 Diperpanjang." 20 Agustus. Retrieved August 28, 2021 (https://hot.liputan6.com/read/4636613/5-upaya-pemerintah-mengatasipandemi-covid-19-selain-ppkm-level-4-diperpanjang).

Makassar.sindonews.com. (2021). "MDMC Sediakan Peti Gratis Untuk Jenazah Muslim Korban Covid-19." 25 Agustus, 1.

MCCC. (2021a). "Laporan Penanganan Covid-19 Muhammadiyah per-3 Agustus 2021." 3 Agustus. Retrieved October 7, 2021 (https://covid19.muhammadiyah.id/laporan-penanganan-covid-19muhammadiyah-per-3-agustus-2021/).

MCCC. (2021b). “MCCC: PPKM Dilonggarkan, Masyarakat Diharapkan Tidak Berlebihan." 23 September.

Merdeka.com. (2020). "Jokowi Apresiasi Kerja Nyata Muhammadiyah Di Tengah Pandemi Covid-19." 18 November. Retrieved August 28, 2021 (https://www.merdeka.com/peristiwa/jokowi-apresiasi-kerja-nyatamuhammadiyah-di-tengah-pandemi-covid-19.html).

Merdeka.com. (2021). "Data Terkini Korban Virus Corona Di Indonesia Pada Juli 2021." $31 \quad$ Julli. Retrieved August 25, 2021 (https://www.merdeka.com/peristiwa/data-terkini-korban-virus-corona-diindonesia-pada-juli-2021.html).

Mettamedia.co.id. (2021). "MDMC Gelar Edukasi Teknik Pembuatan Oksigen Darurat." 15 Juli 1. Retrieved October 7, 2021 (https://mettamedia.co.id/mettanews-detail.php?ID=2685).

Nurhazzanah, Siti. (2016). "Kontribusi Humas Dinas Pariwisata Dan Ekonomi Kreatif Provinsi Riau Dalam Mempromosikann Event Pacu Jalur." Universitas Islam Negeri Sultan Syarif Kasim.

Oxford. (2021). "Definition Disaster." Retrieved September 25, 2021 (https://www.oxfordlearnersdictionaries.com/definition/english/disaster?q=disa ster).

Portal.bangkabaratkab.go.id. (2021). "Pemkab Bangka Barat Terima Bantuan Penekanan Kasus Covid 19 Dari MDMC Kabupaten Bangka Barat." 5 Agustus.

Rao, M. Kavita. (2020). "Disaster Management-Contribution of Scientific and Other Institutions of Higher Learning." V(li).

Ratini, ni Ketut, and Gede Bambang Adi Susanto. 2018. “Upaya Mabayuh Di Griya 
Gede Manuara Desa Balinggi Kecamatan Balinggi Kabupaten Parigi Moutong." STAH Dharma Sentana Sulawesi Tengah.

Rizal, Fitra, \& Haniatul Mukaromah. (2020). "Filantropi Islam Solusi Atas Masalah Kemiskinan Akibat Pandemi Covid-19." AL-MANHAJ: Jurnal Hukum Dan Pranata Sosial Islam 3(1):35-66. doi: 10.37680/almanhaj.v3i1.631.

Sadikin, Sadikin. (2021). "The Transformation of MDMC Social Piety in Forming Public Spaces in the Middle of the Covid-19 Pandemic in Transformasi Kesalehan Sosial MDMC Dalam Pembentukan Ruang Publik Di Tengah Pandemi Covid-19 Di Indonesia." Halaqa: Islamic Education Journal 5(1):2128. doi: 10.21070/halaqa.v5vi1i.1144.

Sorong.terkini.id. (2020a). "MCCC Kampanye Pencegahan Covid-19 Pada Siswa MTs Mutu, Kurniawati Shalihah: Langkah Baik Menyambut Semester Baru." 18 Desember.

Sorong.terkini.id. (2020b). "MDMC Kota Sorong Perkuat Tim Terkait Pencegahan Covid-19." 14 April.

Suaramuhammadiyah.id. (2021). "Muhammadiyah Sebagai Gerakan Filantropi: Perspektif Historis Dan Sosiologis." 3 Maret. Retrieved October 21, 2021 (https://suaramuhammadiyah.id/2021/03/03/muhammadiyah-sebagaigerakan-filantropi-perspektif-historis-dan-sosiologis/).

Suci, Ilda Cita, Napsuparmna Napsuparman, \& Rusma Rusman. (2020). "Understanding Muhammadiyah's Role in Non-Formal Institutions as an Islamic Movement In Acing Covid-19." EduPsyCouns Journal 2:555.

Tempo.co. (2020). "PP Muhammadiyah Bentuk Tim Covid-19 Command Center." 6 Maret, 1.

Timlo.net. (2021). "MDMC Klaten Dirikan Dapur Umum Bantu Logistik Relawan Dan Isoman." 29 Juli, 1.

Tirto.id. (2021). "Grafik Covid Indonesia Juli Jauh Dari Target Dan Tak Terkendali." 30 Juli. Retrieved August 28, 2021 (https://tirto.id/grafik-covid-indonesia-juli2021-jauh-dari-target-tak-terkendali-gicx).

Ulinuha, Muahmmad Taufiq, \& Rose Ana Anggun Fajariah. (2020). "Peran Universitas Muhammadiyah Surakarta DalamPercepatan Penanganan COVID-19 MelaluiProgram Gerakan UMS Peduli." University Research Colloqium 12.

Yulianti, Nur Indah. (2020). "Strategi Fundraising Zakat Infaq Sedekah Di Badan Amil Zakat Nasional (BAZNAS) Kabupaten Cilacap Pada Masa Pandemi Covid-19." iAIN Purwokerto. 